\title{
Practice Education of Environmental Engineering Based on Occupational Skill Improvement
}

\author{
Changwen Ma \\ College of Engineering \\ Shanghai Second Polytechnic University \\ Shanghai, China \\ cwma@sspu.edu.cn
}

\author{
Mingyuan Zhou, Xiuli Li \\ College of Engineering \\ Shanghai Second Polytechnic University \\ Shanghai, China
}

\begin{abstract}
A practice teaching mode of environmental engineering was developed to improve the occupational skills of undergraduates. The guiding ideology to implement the mode was the collaborative development of discipline construction and specialty construction. Practice teaching mode comprised basic practice, comprehensive practice, engineering practice and innovation practice. Students were leaded to strengthen the theoretical knowledge system, to implement the technical method, and to fully exercise the practice skills in the graduation design process. Exploration and practice lasting several years revealed some satisfactory achievements. The graduates' occupational skills have been greatly improved; the employment competitiveness was stronger than others outside the team. In addition, the teachers' educational ability has been improved gradually. The results may be useful for the talents cultivation in the university oriented skilled personnel.
\end{abstract}

Keywords-practice teaching mode; occupational skill; employment competitiveness; undergraduate education;

\section{INTRODUCTION}

To construct the occupational education system and cultivate professional talents is one of targets of the education reformation in China. In recent years, the supply of professional talents is not adequate to the demand in employment market. Occupational skills can be defined as the ability to accomplish a certain job in a specific professional or situational context in which the knowledge, skills and attitudes of the individual will be formed [1]. Higher education is not equal to the senior talent has become a consensus, compared to the education background, sometimes professional skills is more important and more realistic for the enterprises. Whether students have good vocational skill is a prerequisite for the favorable employment. It is significant for those colleges oriented application talents training to improve the quality of occupational graduates, and hence the long-term contribution is reflected in promoting the transformation of economic growth mode and the social harmony and stability [2].

Shanghai Second Polytechnic University regards the higher education oriented career business as the way of running schools, and has established the talents training objectives of "occupational skills + professional ethics + career characteristics". In recent years, according to the innovation and practice of environmental engineering technology, the research team developed the environmental engineering practice teaching system oriented the occupational skill improvement, and on this basis, the environmental engineering practice teaching mode has been proposed and implemented depending on the discipline and professional development each other, and satisfactory results has been achieved.

\section{Construction of The Practice Teaching Mode ORIENTED THE OCCUPATIONAL SKILLS IMPROVEMENT}

\section{A. Position of Environmental Engineering Occupational Skills}

In brief, the occupational skills of the students majored in environmental engineering is to utilize the environmental engineering theory knowledge to solve the practical problems in environmental engineering field [3]. It is not enough for those environmental engineering graduates only to master the theoretical knowledge in book; moreover they need to apply the theoretical knowledge to solve practical problems. There are three basic requirements of vocational skills, namely theoretical knowledge reserves, technical methods and engineering practice.

\section{B. Guiding Ideology of Practice Teaching Mode}

The level of discipline construction reflects the function of scientific research, the ability and the level of running a university, and the level of professional construction reflects the function, quality and effect of the training of talents in colleges and universities [4]. For the development of local university oriented career talents, professional construction and discipline construction is bound to rely on each other to develop collaboratively in order to make the school to maintain good competitiveness and considerable development potential. Therefore, the design and implementation of environmental engineering practice teaching mode has always been guided by the collaborative development of discipline construction and specialty construction [5].

\section{Frame System of Practice Teaching Mode}

Practice teaching mode which is shown in Fig.1 has been developed from basic practice, comprehensive practice, engineering practice and innovation practice. 
Freshman + sophomore

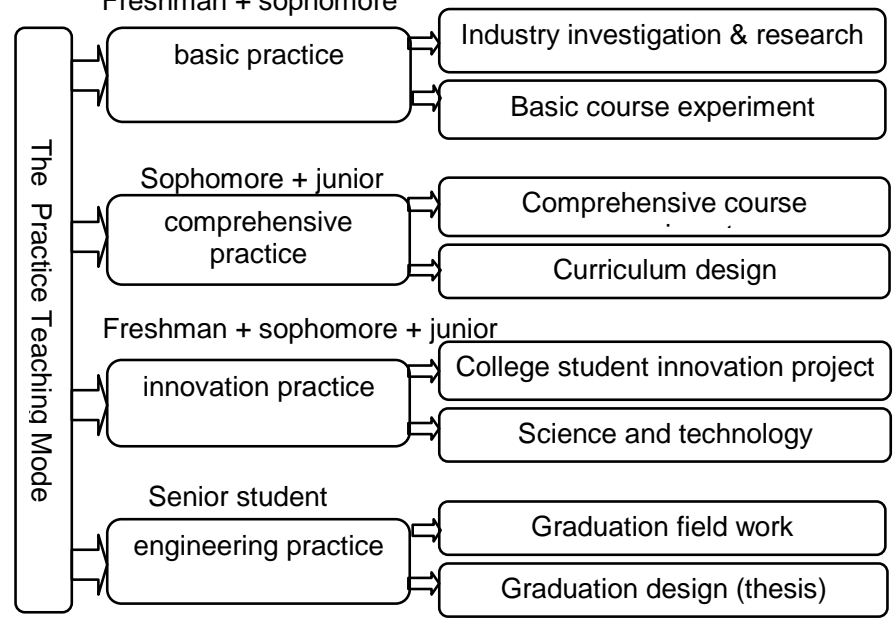

Fig. 1. the Frame System of Practice Teaching Mode

It can be seen from Fig. 1 that the corresponding teaching system has been designed to highlight the practical characteristics.

(1)All-Round Engineering Cognition Practice. Engineering means the producing practice; technology refers to methods, systems, and devices which are the result of scientific knowledge being used for practical purposes [6]. Enhancing the students' professional skills means improving the students' ability of producing practice and increasing the technical reserves, so the engineering cognitive practice is the basis of occupational skills improvement. In the four years of training, through the business visits, industry research, engineering lectures, and summer social practice and so on, students can obtain the entire career awareness, and enhance their learning purpose and initiative.

(2)Respective Occupational Skills Upgrading Program. Each student in team acquires individual occupational skills improvement program according to his own interest. For example, some students are interested in modern instrument, then teachers pay attention to the methods and technologies using instruments in environmental monitoring and remediation of water, air and solid waste contamination in the teaching and learning activities in practice. With the help of advanced precision instruments, teachers strengthen the training and exercise of experimental and research ability and engineering ability solving practical problem. If some students are interested in technology and equipments, teachers have a preference to the design, manufacture, operation, management and development of environmental equipments in the practice of teaching activities.

(3)Innovative Ideas in Whole Practice Process. In teaching practice, the design of innovation projects, all kinds of science and technology competitions, daily participation in scientific research activities and other practical chances are arranged logically. As a kind of ideology, the innovation awareness runs through the whole practice process. From the initial passive learning to the initiative exploration, from passive participation in research projects to the initiative application of scientific projects and competition, the concept and spirit of innovation has been recognized, accepted and practiced by students step by step, the students' professional skills have been improved gradually and deduced adequately in the graduation design segment. Such practical guidance and incentive program not only improve the students' learning enthusiasm, but also cultivate the students' practical ability and innovative spirit. Such program also helps to avoid the common problems in the graduation design (thesis) segment; the overall improvement of the quality of graduation design is expected, and the employment competitiveness of graduates is upgraded consequently.

\section{IMPLEMENTATION OF THE PRACTICE TEACHING ModE ORIENTED OCCUPATIONAL SKILLS IMPROVEMENT}

The cultivation and training of professional skills in school period is a comprehensive education project, in addition to the conventional training plan, the practice teaching mode focus on the following three aspects.

\section{A. Strengthening the Prolongation of Theoretical Knowledge System}

Well-knit and entire theoretical knowledge system is the basis for professional skills. It is one of the most direct and effective ways to develop practical skills for students to study with practical problems. Students become one of scientific research teams when they are enrolled in university according to their interests, they participate in the teachers' scientific research activities and engineering practice to understand the professional field, through analyzing the practical problems and finding out the answer, they accept the classroom theoretical knowledge. The abilities to find, think, analyze and solve practical problems are cultivated as a result. The training in scientific research activities is requited with the solid theoretical foundation, as well as the skilled experimental operation, scientific thinking habit, and the study consciousness from practice.

\section{B. Actualizing the Professional Methods and Technologies}

Students are encouraged to apply for innovative projects, through the project's design and implementation students can experience the complete process including the choice of technical methods, the creation of experimental conditions, the utilize of instruments and equipments, and writing research reports and so on. The engineering practice ability can be enhanced in actualizing the professional methods and technologies. Many years of teaching practice shows that the students are very interested in various levels of innovation projects because of the experience of the project, independent finance of the special funds, and the achievability to independently solve professional practical problems and so on. Such enthusiasm of study is very helpful for the professional skills improvement.

\section{Deduction of Engineering Practical Ability}

The key segment of the practice teaching mode is the graduation design (thesis) which reflects the knowledge reserves, innovation ability and practical skill. In order to 
improve the quality of graduation design (thesis) and the students' occupational skills, the topics design and time arrangement have been treated specially. Firstly the topics of thesis were designed focusing on the teacher's scientific research to make sure of the logistic evolvement; each student's research direction was combined with his usual scientific research activities. Because students had the corresponding research accumulation, every student could quickly make headway in graduation design (thesis). Secondly in time arrangement, the exploration of graduation design direction has been carried out in junior period. Field investigation and laboratory tests had been done during the latter half of junior and first half of senior period. After the opening ceremony of graduation design, students began to sum up the results or to complete tests replenishment, and then began to write the thesis. With the abundant accumulation and enough time, students have the conditions to write a higher quality of graduation thesis. The topic of the graduation design are closely linked to the development of the discipline of demand as well as the engineering practice, meanwhile the study of graduation design is the continuation of pre-research projects. It benefits students in the aspects to master the basic knowledge and to exercise the professional practical ability. Students also agree with this systematic, successive research.

\section{PRACTICAL TEACHING ACHIEVEMENTS BASED ON THE PROMOTION OF OCCUPATIONAL SKILLS}

After more than 7 years of exploration, the practice teaching mode of occupational skills upgrading has gradually matured and revealed a good development prospects, and some satisfactory results have been achieved in the personnel training, discipline construction and professional construction which is listed in Table 1.

TABLE I. ACHIEVEMENTS IN THE PRACTICE BASED ON OCCUPATIONAL SKILL IMPROVEMENT

\begin{tabular}{|c|c|}
\hline Category & Contents \\
\hline \multirow{5}{*}{$\begin{array}{l}\text { discipline } \\
\text { construction }\end{array}$} & $\begin{array}{l}3 \text { scientific research achievements at the municipal } \\
\text { level }\end{array}$ \\
\hline & more than 10 of high level academic papers published \\
\hline & 7 patents during application or authorization \\
\hline & more than one million of annual research funding \\
\hline & $\begin{array}{l}\text { the results of research project are confirmed to be } \\
\text { international initiative }\end{array}$ \\
\hline \multirow{5}{*}{$\begin{array}{l}\text { specialty } \\
\text { construction }\end{array}$} & 2 key courses in university \& 1 key municipal course \\
\hline & 8 educational papers published \\
\hline & $\begin{array}{l}5 \text { awarded students' scientific and technological } \\
\text { innovation projects }\end{array}$ \\
\hline & 1 or more outstanding graduation design each year \\
\hline & 1 awarded outstanding teaching by teams \\
\hline \multirow{3}{*}{$\begin{array}{l}\text { teachers team } \\
\text { construction }\end{array}$} & 1 introduction of young teachers in team \\
\hline & 1 associate professor of promotion \\
\hline & 2 teachers abroad practice training \\
\hline
\end{tabular}

\section{A. Fruits in Talents Cultivation}

From the recent 4 years of teaching practice, the teaching and research team of 5 teachers, around the discipline construction demands have guided students to undertake total 15 scientific and technological innovation projects at all levels, 7 of which won in the reward, the financial funds increased year by year. Among the 41 graduates, 12 people have been awarded as the outstanding graduate or excellent graduation design (thesis); the $29 \%$ excellent rate is much higher than the average level of $10 \%$ of all graduates in the university.

\section{B. Promotion in Employment Competitiveness of Graduates}

Through the implementation of the practice teaching mode, the graduates in the employment performance showed a strong competitiveness, each graduate in the team got a satisfactory job, the employment units such as large state-owned company, commercial bank and environmental protection technology companies and the average salary are also satisfactory.

\section{Improvement in Teachers' Educational Ability}

In the implementation of the practice teaching, the teachers also do front-line business in enterprises to know well engineering practice knowledge and to understand the actual production needs; teachers also cooperate with enterprises to carry out scientific research to solve the problems in enterprise production. Such work not only can provide the students with the latest and most practical teaching material, but also exercise teachers' ability to work. Teachers and students finished together the research project "Thermal compression drying technology and application for solid-liquid separation of ultra-fine particle suspensions", the scientific results are identified as an international initiative, and the project level belongs to the international advanced. The team has been charged with 5 scientific research projects at all levels and 4 enterprise cooperation projects in recent 4 years. More than 20 academic articles has been published, 3 courses has been funded as the key courses in municipal and school construction. There were 1 teaching achievement award and 1 outstanding teaching award; more than that, professional ranks and title of the teachers also have been upgraded.

\section{CONCLUSIONS}

The occupational skills of the undergraduate graduates play an important role in the employment. High skilled personnel training is one of the important tasks of undergraduate education, there are a lot of training modes. A practice teaching mode of environmental engineering was developed by the team taking account of the collaborative development of discipline construction and specialty construction. The practice reaching mode emphasized the promotion of the competitiveness of graduates' employment, the team has explored and practiced for several years. The results show that the practice teaching mode is effective in upgrading the occupational skills of graduates. It is testified that the teaching mode can promote the collaborative development of discipline construction and specialty construction. The results may be helpful for the talents training in others environmental engineering specialty. 


\section{ACKNOWLEDGMENT}

The work has been supported by Cultivate discipline fund of Shanghai Second Polytechnic University (XXKPY1303). The work was funded by Shanghai Municipal Education Commission as the key course construction. The authors also express the sincere appreciations to all the editors and reviewers of this manuscript.

\section{REFERENCES}

[1] Baixiang Ren and Guibo Wang, "The exploration and practice of the Environmental Engineering Studengts' professional Skill Training in normal colleges project," Journal of Jilin Normal University (Humanities \& Social Science Edition), vol. 4, pp. 91-93, 2011. [in Chinese]

[2] Xianchun Niu, Changmei Jia, Ningyu Tu and Meiqin Cen, "Based Environmental Engineering "Trinity" Training Mode and Practice
Teaching System Design Platform,” Guangdong Chemical Industry, vol. 41, pp.114-115, 2014. [ in Chinese]

[3] Edward F .Crawley, Jianzhong Zha, Johan Malmqvist and Doris R. Brodeur, "On Engineering Education Environment," Higher Engineering Education Research, vol. 4, pp.13-21, 2008. [in Chinese]

[4] Bo Fu, He Liu, Xiaoying Cheng and Hongbo Liu. "Exploration and Consideration on the Cultivation of Environmental Engineering Talents with International View," Da Zhong Ke Ji, vol.14, pp. 156-158, 2012. [ in Chinese]

[5] Xiuli Li, Mingyuan Zhou, Li Fan and Changwen Ma. "Research and practice of CIE-CDIO cultivation mode for the environmental engineering specialty," Conference on Education and Teaching in Colleges and Universities (CETCU), Weihai, China, 2013, pp. 479-483.

[6] Li Shen, Yucui Hao and Xiujun Sun, "Research and Practice of Environmental Engineers Training Mode in the Applied Undergraduate Colleges," Guangdong Chemical Industry, vol. 41, pp. 212-213, 2014. [in Chinese] 